\title{
Pelatihan Pembelajaran PAI Berbasis Daring bagi Guru TK di Kecamatan Mranggen Demak
}

\author{
Khoirul Anwar*, Choeroni, Toha Makhshun \\ Pendidikan Agama Islam, Fakultas Agama Islam, Universitas Islam Sultan Agung (UNISSULA), \\ Semarang, Indonesia \\ *Corresponding Author \\ Jl. Raya Kaligawe KM.4 Semarang 50112 Indonesia \\ Email: khoirul@unissula.ac.id

$\begin{array}{lccc}\text { Received: } & \text { Revised: } & \text { Accepted: } & \text { Published: } \\ \text { 17 January 2021 } & \text { 26 May 2021 } & \text { 23 September 2021 } & \text { 27 November 2021 }\end{array}$

\begin{abstract}
Abstrak
Pada masa pandemi covid-19 sekarang ini, kegiatan pembelajaran jarak jauh (PJJ) di semua tingkatan dan jenjang pendidikan, khususnya di tingkat taman kanak-kanak mengalami berbagai tantangan dan kendala. Di antaranya masih banyak guru yang mengalami kesulitan mengelola pembelajaran jarak jauh karena keterbatasan mereka dalam menguasai pembelajaran berbasis daring. Sementara itu, kendala yang dihadapi orang tua murid adalah ketidaksiapan mereka dalam mendampingi anaknya dalam pembelajaran berbasis daring. Kondisi demikian menjadikan pelatihan pembelajaran berbasis daring bagi para guru dan orangtua murid sebagai salah satu solusi dalam mengatasi kendala pembelajaran di masa pandemi. Inilah yang menjadikan arti penting kegiatan pengabdian saat pendemi seperti sekarang ini bagi guru-guru yang menjadi garda terdepan dalam kegiatan pembelajaran. Metode dalam kegiatan pengabdian ini dilakukan dengan cara pelatihan dan pendampingan. Hasilnya, para peserta mampu mempergunakan berbagai aplikasi pembelajaran daring. Implikasi yang diperoleh dari kegiatan ini adalah bertambahnya keterampilan menerapkan teknologi pendidikan dalam kegiatan pembelajaran berbasis daring bagi guru-guru TK di Kecamatan Mranggen-Demak.
\end{abstract}

Kata Kunci: Pengajaran Daring; Pembelajaran Agama Islam

\begin{abstract}
During the Covid-19 pandemic, distance learning activities (PJJ) at all levels and levels of education, especially at the kindergarten level, experience various challenges and obstacles. Among the many teachers who experience distance learning difficulties because of their limitations in mastering online-based learning. Meanwhile, schools that are related to students' parents are their unpreparedness in assisting children in online-based learning. This condition makes online-based learning training for teachers and parents of students as one of the solutions in overcoming learning problems during the pandemic. This is the important meaning of service activities during a pandemic like it is today for teachers who are at the forefront of learning activities. The method in this service activity is carried out by means of training and mentoring. As a result, the participants were able to use various online learning applications. The implication obtained from this activity is the development of the application of educational technology in online-based learning activities for kindergarten teachers in Mranggen-Demak District.
\end{abstract}

Keywords: Online teaching; Islamic learning 


\section{PENDAHULUAN}

Analisis Situasi

Sampai saat ini penyebaran virus Covid-19 masih terjadi, sehingga memaksa berbagai lembaga pendidikan dari semua tingkatan dan jenjang pendidikan melakukan kegiatan pembelajaran berbasis daring. Kondisi demikian berkenaan dengan upaya pemerintah untuk memutus mata rantai penyebaran dan penularan virus Covid-19 di seluruh Indonesia. Kesiapan teknologi dan sumber daya insani (SDI) menjadi kata kunci dalam menghadapi situasi pandemi seperti sekarang ini, dimana kegiatan pembelajaran menggunakan model daring. Kegiatan Belajar Mengajar (KBM) dari yang biasanya tatap muka di kelas (offline) menjadi bersifat virtual dan berbasis online atau daring (dalam jaringan).

Ketika awal pemerintah mengeluarkan kebijakan tentang pembelajaran daring, banyak guru yang belum siap untuk melaksanakannya (Almarzooq et al., 2020), apalagi di sekolahsekolah yang belum terbiasa menggunakan pembelajaran daring. Dengan kata lain, kebijakan pembelajaran daring saat itu diambil karena dalam keadaan "darurat". Guru belum dipersiapkan secara optimal, begitu pula dengan siswa maupun orang tua. Padahal kesiapan guru menjadi hal yang sangat penting, karena guru merupakan bagian sumber daya insani (SDI) di sekolah yang memberikan pengaruh terhadap keberhasilan peserta didik dalam pembelajaran. Selain itu, kesiapan guru menghadapi pembelajaran daring juga ikut menentukan keberhasilan pembelajaran peserta didik, seperti kesiapan menyusun RPP, menyiapkan materi dan media pembelajaran serta pengaturan jadwal pembelajaran daring (Alwiyah \& Imaniyati, 2018; Larlen, 2013). Menurut Korth (dalam Ayuni et al., 2020) menyatakan bahwa guru yang memiliki kesiapan dalam pembelajaran akan meningkatkan kualitas guru.

Menghadapi situasi pandemi sekarang ini, setiap lembaga pendidikan, bahkan kegiatan pembelajaran dituntut untuk melakukan inovasi untuk mengatasi situasi, tidak terkecuali pembelajaran Pendidikan Agama Islam (PAI). Guru PAI dituntut untuk mampu menyesuaikan diri dengan situasi pandemi yang mengharuskan kegiatan pembelajaran memanfaatkan kemajuan teknologi informasi. Bagi sebagian guru, hal ini boleh jadi tidak menjadi masalah berarti, tetapi bagi sebagian besar guru, khususnya guru PAI ini menjadi masalah penting yang perlu dicarikan solusi. Setiap guru PAI dituntut untuk melakukan inovasi di masa pandemi seperti sekarang ini dengan cara mempelajari dan memahami beragam model pembelajaran daring berbasis IT yang cocok dengan karakteristik pembelajaran PAI.

Berhasil dan tidaknya pembelajaran Pendidikan Agama Islam (PAI) yang bermutu sangat berkaitan erat dengan tingkat kompetensi dan profesionalisme guru PAI. Guru PAI merupakan salah satu unsur terpenting dalam keberhasilan penyelenggaraan Pendidikan Agama Islam (PAI) di sekolah, termasuk di Taman Kanak-kanak (TK) dalam menanamkan nilai-nilai akhlak dan karakter sejak dini. Pemahaman Nilai-nilai Islam perlu dilakukan sejak dini agar menjadi fondasi yang kuat dalam penanaman dan pembentukan akhlak dan karakter peserta didik. Optimalisasi pendidikan akhlak dan karakter, sebaiknya memang harus dimulai dari para gurunya sendiri (Wibowo, 2016), apalagi anak-anak TK yang lebih cenderung meniru perilaku orang dewasa. Pembelajaran PAI pada TK harus mempertimbangkan tingkat perkembangan peserta didik, sehingga dalam proses pembelajaran tersebut dapat menumbuhkan potensi anak sesuai fase perkembangannya. Begitu pula dalam pendekatan pembelajarannya, juga disesuaikan dengan masa perkembangannya, yakni belajar sambil bermain.

Penyelenggaraan pembelajaran Pendidikan Agama Islam (PAI) pada Taman KanakKanak (TK) dapat berlangsung secara baik dan bermutu bilamana kegiatan pembelajarannya dikelola sesuai dengan prinsip-prinsip pembelajaran pada usia dini. Menurut Carton dan Allen 
sebagaimana dikutip oleh Sujiono (2009), bahwa peran guru anak usia dini lebih sebagai mentor atau fasilitator, dan bukan sebagai pentransfer ilmu pengetahuan semata, karena pada dasarnya, ilmu tidak dapat ditransfer dari guru kepada anak tanpa dibarengi keaktifan anak itu sendiri.

Pembelajaran merupakan kegiatan yang di dalam pelaksanaannya melibatkan guru, orang tua atau walimurid dan murid atau peserta didik. Untuk memperoleh hasil yang maksimal dalam pembelajaran Pendidikan Agama Islam (PAI), maka perlu dilakukan upaya pengelolaan terhadap seluruh komponen kegiatan pembelajaran agama Islam melalui tindakan-tindakan strategis untuk mencapai hasil pembelajaran secara maksimal (Qomar, 2018). Untuk itu, agar pembelajaran Pendidikan Agama Islam (PAI) di TK dapat berjalan dengan baik, diperlukan peran guru di sekolah dan peran orang tua di rumah untuk membimbing dan mendampingi anaknya, apalagi bila pembelajarannya menggunakan sistem daring seperti saat ini.

Permasalahannya, bukan sekedar mengalihkan proses Kegiatan Belajar Mengajar (KBM), tetapi apakah sekolah sudah siap melaksanakan pembelajaran daring, baik secara teknologi maupun sumber daya insani (SDI) yang ada, terutama sekolah-sekolah yang ada di desa atau bahkan di daerah-daerah terpencil. Bila melihat kenyataan di lapangan, tentunya belum semua lembaga pendidikan siap untuk melaksanakannya, khususnya terkait dengan kesiapan teknologi maupun sumber daya insaninya (SDI), terutama guru sebagai garda terdepan dalam mensukseskan kegiatan pembelajaran daring di masa pandemi. Kesiapan yang dimiliki guru TK dalam pembelajaran berpengaruh kepada keberhasilan program pendidikan di sekolah, sehingga guru yang memiliki kesiapan yang baik akan membantu meingkatkan belajar peserta didik (Arini \& Kurniawati, 2020; Dewi \& Suryana,2020; Mundiasari \& Setiawan, 2020; Sum \& Taran, 2020).

Untuk mengatasi minimnya pengetahuan tentang pembelajaran berbasis daring bagi guruguru TK sebagai salah satu solusinya pihak pengelola sekolah membutuhkan pihak-pihak yang dapat membantu masalah persoalan kesiapan sumber daya insani (SDI) tersebut, baik berupa pelatihan maupun pendampingan pembelajaran daring. Kegiatan ini diperlukan bukan hanya sekedar menghadapi pandemi Covid-19 seperti sekarang ini, tetapi lebih dari itu juga untuk menyiapkan sumber daya insani, khususnya guru-guru yang memiliki kompetensi IT yang lebih baik dalam menghadapi kemajuan ilmu pengetahuan dan teknologi. Dengan demikian, pelatihan tersebut diharapkan menjadi solusi terhadap permasalahan mitra.

Guna menjembatani kondisi tersebut di atas, maka pengabdian masyarakat dengan judul "Pelatihan Pembelajaran Pendidikan Agama Islam (PAI) Berbasis Daring bagi Guru-Guru TK di Kecamatan Mranggen Demak" ini akan menjadi salah satu solusi bagi masyarakat dalam menghadapi situasi seperti sekarang ini. Selain itu, kegiatan ini juga merupakan upaya tim pengabdian kepada masyarakat untuk mengenalkan kepada masyarakat tentang pembelajaran berbasis daring sebagai tuntutan kondisi saat ini, sekaligus sebagai tuntutan perkembangan jaman dan kemajuan ilmu pengetahuan dan teknologi. Oleh karena itu, kegiatan pengabdian masyarakat ini menjadi hal yang penting untuk dilakukan baik pada saat pandemi sekarang ini maupun pada masa yang akan datang. Kegiatan ini juga sebagai wujud kepedulian UNISSULA terhadap masyarakat, sebagai implementasi dari Visi "Bismillah Membangun Generasi Khaira Ummah" yang salah satu indikatornya adalah bermanfaat bagi orang lain atau "anfauhum linnas", yang juga sekaligus sejalan dengan roadmap pengabdian masyarakat di FAI maupun UNISSULA. 


\section{Permasalahan Mitra}

1. Minimnya pengetahuan tentang pembelajaran Pendidikan Agama Islam (PAI) berbasis daring bagi guru-guru TK di Kecamatan Mranggen Demak

2. Minimnya pengetahuan tentang pendampingan pembelajaran Pendidikan Agama Islam (PAI) berbasis daring bagi wali murid di TK Kecamatan Mranggen Demak

3. Minimnya sumber daya insani (SDI) di TK Kecamatan Mranggen Demak yang memiliki kompetensi di bidang pembelajaran berbasis IT

\section{Solusi dan Luaran}

Solusi yang diberikan dalam kegiatan pengabdian pada masyarakat untuk mengatasi permasalahan tersebut adalah :

1. Memberikan pelatihan pembelajaran Pendidikan Agama Islam (PAI) berbasis daring kepada guru sebagai garda terdepan pembelajaran daring di sekolah.

2. Memberikan pelatihan pembelajaran Pendidikan Agama Islam (PAI) berbasis daring kepada wali murid sebagai garda terdepan saat pembelajaran daring di rumah.

3. Memberikan pendampingan ke pihak sekolah untuk menyiapkan sumber daya insani (SDI) yang siap melaksanakan pembelajaran berbasis daring.

Luaran yang dicapai dari kegiatan pengabdian masyarakat ini adalah terbagi menjadi dua, yaitu :

1. Lembaga-lembaga pendidikan/ sekolah terbantu dengan adanya sumbangan akun Zoom Premium dari tim pengabdian masyarakat Fakultas Agama Islam (FAI) Universitas Islam Sultan Agung (UNISSULA) kepada perwakilan dari beberapa TK di Kecamatan Mranggen Demak untuk menunjang lancarnya penerapan pembelajaran berbasis daring.

2. Lembaga-lembaga pendidikan / TK yang mengirimkan guru-gurunya untuk mengikuti pelatihan pembelajaran PAI berbasis daring, akhirnya memiliki sumber daya insani (SDI), yang memiliki kompetensi di bidang teknologi pembelajaran guna mendukung pembelajaran berbasis daring.

\section{METODE PELAKSANAAN}

1. Sosialisasi

a. Sosilisasi kebijakan Pemerintah tentang pembelajaran daring di masa pandemi untuk memutus mata rantai penyebaran virus Covid-19 karena masih ada sekolah yang tetap melaksanakan pembelajaran secara langsung atau offline.

b. Sosialisasi pentingnya penanaman akhlak sejak dini melalui pembelajaran PAI berbasis daring. Mengingat bahwa pendidikan pada dasarnya tidak dapat terlepas

2. Pelatihan dari nilai-nilai yang ingin ditanamankan kepada siswa (Kumalasari, 2018).

Tim pengabdian masyarakat memberikan pelatihan pembelajaran PAI berbasis daring bagi guru-guru TK di kecamatan Mranggen Demak

\section{Praktik Mengajar}

Tim pengabdian masyarakat mempraktikkan secara langsung pembelajaran Pendidikan Agama Islam (PAI) berbasis daring melalui zoom kepada peserta pelatihan. 


\section{HASIL DAN PEMBAHASAN \\ Hasil}

Program pengabdian masyarakat dalam bentuk pelatihan pembelajaran Pendidikan Agama Islam (PAI) berbasis daring yang semula direncanakan hanya untuk guru-guru dan walimurid TKIT Aulia Rahman Wringinjajar-Mranggen-Demak ini ternyata akhirnya diikuti juga perwakilan dari guru-guru TK di Kecamatan Mranggen Demak, sehingga hasilnya lebih luas dibanding dari rencana semula yang hanya satu TK. Selain para peserta memperoleh sosialisasi kebijakan pemerintah tentang pembelajaran jarak jauh (PJJ), materi tentang urgensi pendidikan akhlak sejak dini, pelatihan pembelajaran Pendidikan Agama Islam (PAI) berbasis daring, juga memperoleh bantuan akun Zoom premium yang dapat membantu suksesnya pelaksanaan kegiatan pembelajaran berbasis daring.

\section{Pembahasan}

Kegiatan pengabdian kepada masyarakat ini berawal dari keprihatinan tim pengabdian kepada masyarakat Fakultas Agama Islam (FAI) Universitas Islam Sultan Agung (UNISSULA) Semarang kepada lembaga-lembaga pendidikan atau sekolah-sekolah di beberapa desa yang belum siap menjalankan kebijakan pemerintah tentang pembelajaran jarak jauh (PJJ), terutama di jenjang pendidikan TK. Lalu kami menawarkan bagaimana kalau guru yang merupakan garda terdepan dalam pembelajaran di sekolah diberi pembekalan dan pelatihan tentang teknologi pendidikan, khususnya dalam merespon kebijakan pemerintah tentang pembelajaran berbasis daring di masa pandemi ini. Ternyata gayung bersambut, gagasan ini direspon oleh pihak yayasan "Hidayatus Sholihin" yang selama ini menaungi TKIT Aulia Rahman Wringinjajar Mranggen Demak.

Selanjutnya ditentukan model kegiatan pengabdiaan kepada masyarakat yang dilaksanakan dalam bentuk pelatihan pembelajaran berbasis daring, dengan materi tentang Pendidikan Agama Islam (PAI). Sedangkan pesertanya semula adalah untuk guru-guru di lingkungan TKIT Aulia Rahman Wringinjajar Mranggen Demak dengan pertimbangan, bahwa guru merupakan sumber daya insani (SDI) yang menjadi tulang punggung dan sekaligus garda terdepan dalam mensukseskan pembelajaran di sekolah. Kemudian peserta lainnya adalah dari orang tua murid atau walimurid dari TKIT Aulia Rahman Wringinjajar Mranggen Demak, dengan pertimbangan bahwa mereka adalah menjadi garda terdepan dalam mendampingi anakanaknya saat belajar di rumah, mengingat ana-anak TK masih sangat bergantung dengan orang tuanya saat pembelajaran di rumah.

Hanya saja dalam pelaksanaannya, karena kegiatan pengabdian kepada masyarakat dalam bentuk pelatihan ini diselenggarakan secara offline atau tatap muka langsung dengan peserta pelatihan, maka dengan pertimbangan menjaga protokol kesehatan akhirnya diputuskan bahwa pesertanya adalah guru-guru saja. Mengingat kegiatan pelatihan ini dilaksanakan pada saat Jawa Tengah memperketat pemberlakuan protokol kesehatan, sehingga apabila diikuti semua walimurid, maka pesertanya akan banyak sekali, sementara tempatnya sangat terbatas. Sebagai penggantinya, dengan pertimbangan menambah kebermanfaatan yang lebih luas kepada masyarakat, ahirnya pesertanya selain guru-guru dari TKIT Aulia Rahman, juga diikuti guruguru perwakilan dari beberapa TK yang berada di wilayah kecamatan Mranggen Kabupaten Demak, meliputi perwakilan dari TK Ceria, TK Pambudi, TK Menur Semi, TK Mekar Sari dan TK Mutiara Al-Falah. Dengan demikian kebermanfaatannya akan lebih luas, karena para guru dari masing-masing TK tersebut akan menerapkannya dalam pembelajaran di sekolahnya.

Kegiatan Pengabdian masyarakat yang diikuti 24 peserta ini diawali dengan pembukaan oleh kepala TKIT Aulia Rahman, kemudian dilanjutkan dengan pembacaan ayat suci AlQur'an. Selanjutnya sambutan-sambutan yang diawali dengan sambutan dari ketua asosiasi guru TK di Kecamatan Mranggen Demak yang pada intinya mengucapkan terima kasih yang sebesarbesarnya kepada tim pengabdian masyarakat Fakultas Agama Islam (FAI) Universitas Islam 
Sultan Agung (UNISSULA) Semarang yang telah berkenan hadir untuk membantu memberikan pelatihan pembelajaran PAI berbasis daring kepada guru-guru TK di kecamatan Mranggen Demak. Setelah itu dilanjutkan sambutan dari ketua tim Pengabdian masyarakat, yang pada intinya menjelaskan tentang tujuan pengabdian kepada masyarakat. Setelah kegiatan pembukaan, kemudian dilanjutkan dengan kegiatan pelatihan.

Adapun kegiatan pelatihan ini diawali dengan sosialisasi tentang kebijakan pemerintah tentang pembelajaran jarak jauh (PJJ) oleh Khoirul Anwar. Hal ini penting disampaikan, mengingat masih banyak sekolah-sekolah di desa, termasuk jenjang TK yang tetap melakukan pembelajaran langsung atau secara offline meskipun belum diijinkan oleh pemerintah daerahnya masing-masing. Dengan kondisi seperti ini menjadi sangat rawan akan terjadinya penyebaran virus Covid-19 di TK bilamana tidak dapat menjaga protokol kesehatan, apalagi mereka adalah anak-anak yang masih di bawah umur yang pada umumnya belum paham tentang menjaga kesehatan.

Materi sosialisasi berikutnya disampaikan oleh Choeroni tentang Urgensi pendidikan akhlak sejak dini. Materi ini sangat penting, mengingat bahwa Pendidikan tidak hanya mendidik para peserta didiknya untuk menjadi cerdas saja, tetapi yang tidak kalah penting adalah membangun kepribadiannya agar berakhlak mulia (Azzet, 2014). Pendidikan akhlak hendaknya dilakukan semenjak dini, karena pendidikan akhlak atau karakter itu tidak bisa instan, tetapi harus ditanamkan semenjak awal usia anak. Sehingga dengan pertimbangan bahwa guru-guru di TK menjadi garda terdepan dalam pembelajaran PAI di sekolah, khususnya dalam penanaman akhlak, maka sangat tepat sekali bila mereka dibekali dengan materi akhlak beserta motede pembelajarannya saat seperti sekarang ini.

Selanjutnya Toha Makhshun menyampaikan materi pelatihan pembelajaran PAI berbasis daring dengan memperkenalkan terlebih dahulu mengenai model-model pembelajaran jarak jauh (PJJ), khususnya yang cocok untuk pembelajaran di jenjang Taman kanak-kanak (TK). Kemudian beliau memberikan contoh dan mempraktikkannya langsung kepada peserta pelatihan, termasuk pembelajaran secara daring menggunakan HP atau gadget. Dengan demikian pelatihan menjadi lebih praktis dan mudah dipraktikkan karena cukup menggunakan HP atau gadget yang sudah dimiliki oleh masing-masing peserta.

Akhirnya, guna memperlancar penerapan pembelajaran berbasis daring, maka tim pengabdian masyarakat Fakultas Agama Islam (FAI) Universitas Islam Sultan Agung (UNISSULA) Semarang menyerahkan bantuan berupa akun Zoom premium kepada perwakilan peserta dari masing-masing TK yang menjadi peserta pelatihan. Ini semua kami lakukan dalam rangka membantu terselenggaranya kegiatan pembelajaran jarak jauh (PJJ) di saat pandemi seperti sekarang ini. Hasilnya, peserta akhirnya mampu menerapkan berbagai aplikasi pembelajaran berbasis daring setelah dilakukan pelatihan dan pendampingan.

Berikut adalah gambar sebagian peserta kegiatan pengabdian masyarakat "Pelatihan Pembelajaran PAI Berbasis Daring bagi Guru-Guru TK di Kecamatan Mranggen Kabupaten Demak" yang diselenggarakan di TKIT Aulia Rahman Wringinjajar-Mranggen-Demak. 


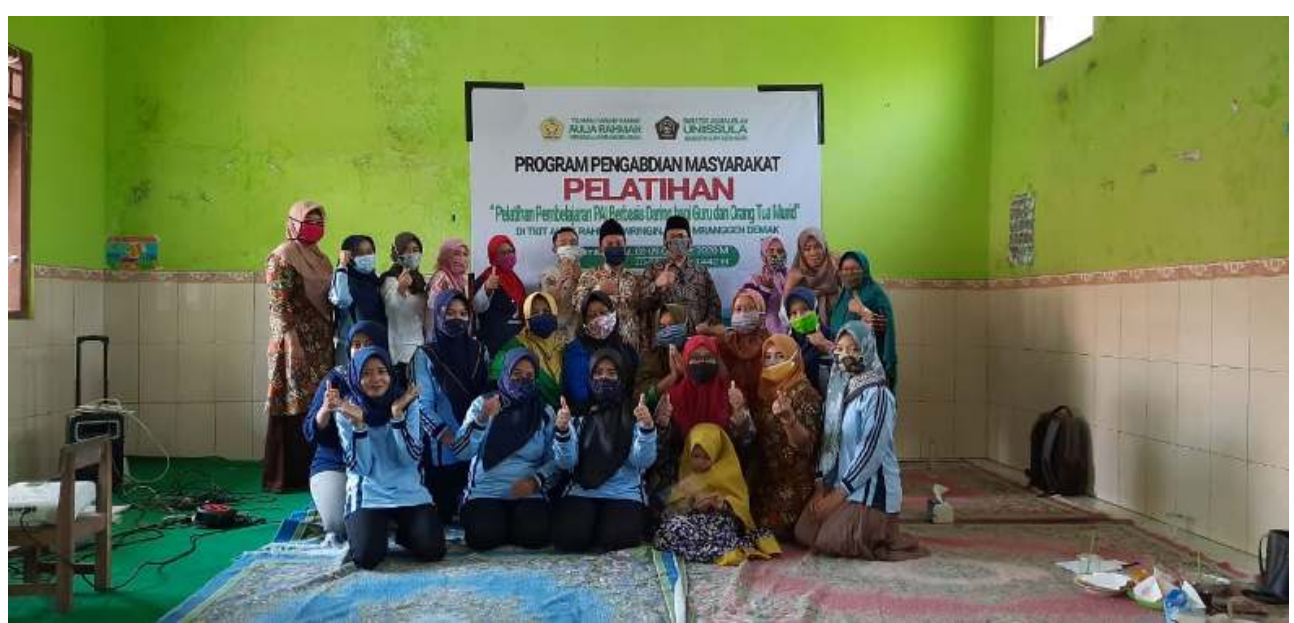

Gambar 1. Peserta pelatihan Pembelajaran PAI Berbasis Daring

\section{KESIMPULAN}

Kegiatan Pelatihan Pembelajaran PAI Berbasis Daring Bagi Guru-Guru TK tersebut merupakan bagian dari kegiatan pengabdian kepada masyarakat di saat pandemi. Kegiatan tersebut diselenggarakan sebagai bentuk partisipasi aktif dari tim pengabdian masyarakat Fakultas Agama Islam (FAI) Unissula untuk mempersiapkan pembelajaran PAI jarak jauh (PJJ) bagi guru-guru TK di kecamatan Mranggen kabupaten Demak. Dengan kegiatan ini, guru-guru TK yang menjadi peserta pelatihan memperoleh penjelasan mengenai kebijakan pemerintah tentang pembelajaran jarak jauh (PJJ) selama masa pandemi. Mereka juga diingatkan akan pentingnya penanaman akhlak atau karakter sejak dini yang menjadi tugas utama seorang guru. Kemudian yang terpenting melalui pelatihan ini, guru-guru TK yang menjadi garda terdepan dalam mensukseskan pembelajaran di sekolah, akhirnya paham dan mampu menerapkan kegiatan pembelajaran berbasis daring. Termasuk masing-masing sekolah terbantu dengan pemberian akun Zoom premium dari tim pengabdian guna menunjang lancarnya pembelajaran daring di sekolah.

\section{UCAPAN TERIMA KASIH}

Kegiatan pengabdian kepada masyarakat ini, dapat terlaksana berkat dukungan dari berbagai pihak. Oleh sebab itu, dalam kesempatan ini perkenankan kami menyampaikan terima kasih kepada Rektor Universitas Islam Sultan Agung (UNISSULA) Semarang, Dekan Fakultas Agama Islam (FAI) Universitas Islam Sultan Agung (UNISSULA) Semarang, Kepala LPPM Universitas Islam Sultan Agung (UNISSULA) Semarang beserta stafnya, Kepala Program Studi Pendidikan Agama Islam (PAI) Fakultas Agama Islam (FAI) Universitas Islam Sultan Agung (UNISSULA) Semarang, Kepala TKIT Aulia Rahman Wringinjajar-Mranggen-Demak, semua peserta pelatihan pembelajaran PAI berbasis daring, dan berbagai pihak yang tidak dapat kami sebutkan satu persatu yang telah membantu terlaksananya kegiatan pengabdian kepada masyarakat. 


\section{DAFTAR PUSTAKA}

Almarzooq, Z. I., Lopes, M., \& Kochar, A. (2020). Virtual Learning During the COVID-19 Pandemic. Journal of the American College of Cardiology, 75(20),2635-2638. https://doi.org/10.1016/j.jacc.2020.04.015

Alwiyah, D., \& Imaniyati, N. (2018). Keterampilan Mengajar Guru dan Kesiapan Belajar Siswa sebagai Determinan Terhadap Hasil Belajar Siswa. Jurnal MANAJERIAL, 17 (1), 95. https://doi.org/10.17509/manajerial.v17i1.9767

Arini, S., \& Kurniawati, F. (2020). Sikap Guru terhadap Anak Usia Dini dengan Autism Spectrum Disorder. Jurnal Obsesi: Jurnal Pendidikan Anak Usia Dini, 4(2),639. https//doi.org/10.31004/obsesi.v4i2.410

Ayuni, D., Marini, T., Fauziddin, M., \& Pahrul, Y. (2020). Kesiapan Guru TK Menghadapi Pembelajaran Daring Masa Pandemi Covid-19. Jurnal Obsesi : Jurnal Pendidikan Anak Usia Dini, 5(1), 414. https://doi.org/10.31004/obsesi.v5i1.579

Azzet, A. M. (2014). Urgensi Pendidikan Karakter di Indonesia. Ar-Ruzz Media.

Dewi, I., \& Suryana, D. (2020). Analisis Evaluasi Kinerja Pendidik Pendidikan Anak Usia Dini di PAUD Al Azhar Bukittinggi. Jurnal Obsesi : Jurnal Pendidikan Anak Usia Dini, 4(2), 1050. https://doi.org/10.31004/ obsesi.v4i2.465

Kumalasari, D. (2018). Agama dan Budaya Sebagai Basis Pendidikan Karakter di Sekolah. Suluh Media.

Larlen, L. (2013). Persiapan Guru Bagi Proses Belajar Mengajar. Pena: Jurnal Pendidikan Bahasa dan Sastra Universitas Jambi,3(1). https://onlinejournal.unja.ac.id/pena/article/view/1452

Lembaga Penelitian dan Pengabdian masyarakat Universitas Islam Sultan Agung Semarang. (2020). Buku Panduan Pengabdian Kepada Masyarakat Internal Universitas Islam Sultan Agung Edisi Tahun 2020.

Mundiasari, \& Setiawan. (2020). Kompetensi Pedagogik Guru dalam Melaksanakan Penilaian Pembelajaran Anak Usia Dini. Jurnal Obsesi: Jurnal Pendidikan Anak Usia Dini, 4(2), 900. https://doi.org/10.31004/obsesi.v4i2.478

Qomar, M. (2018). Manajemen Pembelajaran Pendidikan Agama Islam. Erlangga.

Rukajat, A. (2018). Manajemen Pembelajaan. Deepublish

Sujiono, S. Y. (2009). Konsep Dasar Anak Usia Dini. Indeks.

Sum, T.A., \& Taran, E.G.M. (2020). Kompetensi Pedagogik Guru PAUD dalam Perencanaan dan Pelaksanaan Pembelajaran. Jurnal Obsesi: Jurnal Pendidikan Anak Usia Dini, 4(2), 543. https:/ / doi.org/10.31004/obsesi.v4i2.287

Wibowo, A. (2016). Manajemen Pendidikan Karakter di Sekolah (Konsep dan Praktik Implementasi). Pustaka Pelajar. 